\title{
Participative Management Practices and Institutional Goal Attainment in Nigerian Universities
}

Humanitie

Vol. 5, No. 1, 169-177, 2020

e-ISSN: 2520-5382

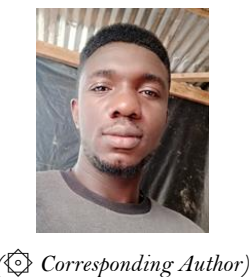

\author{
Garieth Omorobi Omorobi ${ }^{1}$ \\ Usen Friday Mbon ${ }^{2}$ \\ Valentine Joseph Owan ${ }^{3}$ to \\ John Asuquo Ekpenyong"
}

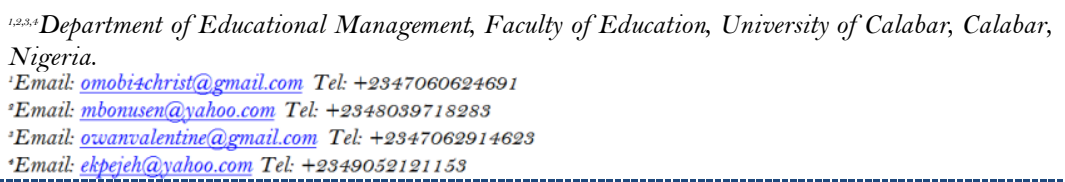

\section{ABSTRACT}

This study evaluated the relationship between participative management practices and institutional goal attainment among Nigerian universities, with University of Calabar in focus. To achieve the purpose of the study, two research questions and two null hypotheses where developed to guide the study. The descriptive survey research design was adopted for the study. The population and sample of the study was one hundred and twenty-two (122) deans of faculties and heads of departments using the census approach. An instrument titled Participative Management Practices and Institutional Goal Attainment Questionnaire (PMPIGAQ) was used for data collection. The instrument was validated by three experts in Higher Education Administration and Measurement and Evaluation. The instrument yielded Cronbach's reliability alpha ranging from $\alpha=.75-86$. Data were collected and analyzed through mean, Standard deviation, Pearson Product Moment Correlation Analysis. The results of the study showed that there is a significant relationship between participation in decision making, participation in planning and institutional goal attainment. It was recommended that managers of universities should promote participatory management practices to enhance high morale, commitment and enthusiasm among staff in the pursuit and attainment of institutional goals.

Keywords: Participative, Management, Institutional, Goal, Attainment.

DOI: $10.20448 / 801.51 .169 .177$

Citation | Garieth Omorobi Omorobi; Usen Friday Mbon; Valentine Joseph Owan; John Asuquo Ekpenyong (2020). Participative Management Practices and Institutional Goal Attainment in Nigerian Universities. American Journal of Social Sciences and Humanities, 5(1): 169-177.

Copyright: This work is licensed under a Creative Commons Attribution 3.0 License

Funding: This study received no specific financial support.

Competing Interests: The authors declare that they have no competing interests.

History: Received: 17 October 2019/ Revised: 19 November 2019/ Accepted: 23 December 2019/ Published: 12 February 2020 Publisher: Online Science Publishing 


\section{Highlights of this paper}

- The relationship between participative management practices and institutional goal attainment among Nigerian universities was the main thrust of the study.

- The results of the study showed that there is a significant relationship between participation in decision making, participation in planning and institutional goal attainment.

- It was recommended that managers of universities should promote participatory management practices to enhance high morale, commitment and enthusiasm among staff in the pursuit and attainment of institutional goals.

\section{INTRODUCTION}

Formal organizations are established to pursue and achieve predetermined goals and objectives. Therefore, the goals and objectives of any institution serve as the yardstick for measuring its effectiveness. Hence, society and critical stake holders form expectations for institutions or organizations in line with the goals and objective they pursue. This makes the achievement of institutional goals critical to both managers and members of any organization. Consequently, universities the World over, are established for the essential goal of producing high quality graduates that can compete favourably with their peers around the globe and serve as critical manpower in all sectors of the economy. In keeping with this, the broad goals and objectives of Nigerian higher education system were articulated in the National policy on education, Federal Government of Nigeria (2013) to include:

1. Contributing to national development through high level relevant manpower training.

2. Developing and inculcating proper values for the survival of the individual and the society.

3. Developing intellectual capability of individual to understand and appreciate their local and external environments.

4. Acquiring both physical and intellectual skills which will enable individuals to be self-reliant and useful members of the society.

However, despite the massification or proliferation of universities in Nigeria, these noble goals and objectives seem not to be achieved as expected. Because the quality of Nigerian graduates has constantly been criticized of lacking the requisite skills and capacity to contribute meaningfully to national development. The Nigerian Institute of Personnel Management as cited in Francis (2015) observed that the quality of graduates from Nigerian universities is declining rapidly. Similarly, National Employers Consultative Association (NECA) lamented that the quality of Nigerian graduates does not meet the demands of industry. This indicates that Nigerian universities have not been able to achieve some of the goals of university education. The seeming inability of Nigerian universities to train the right mix and quality of graduates could be attributed to poor and undemocratic institutional management practices that do not allow for effective participation of members of the university community (academic/nonacademic) in the day to affairs of school life. This is because, the success or failure of any organization highly relies on effective leadership and managerial practices. In fact, poor managerial practices affect employee's perception of institutional vision and values, potentially causing unhappiness and leading to a high turnover. Hence, Koroma (2018) avers that, to circumvent potential negative impacts of managerial approach, there is need for conscious and conscientious development of competent leaders to enhance organizational survival.

Therefore, participative management practices that ensures inclusion of all members of the school is key to achieving the goals and objectives of university education. This is because, modern day universities are large and complex organizations with sophisticated and multifaceted units, missions, objectives and goals. Therefore, no one individual can effectively pursue and achieve their objectives alone by their very nature. These complex and highly specialized disciplines, faculties, colleges, non-academic departments and units in universities require technical 
knowledge and competence to achieve their objectives, and such knowledge cannot be resident in any one administrator, no matter how powerful. Consequently, Ogunruku (2010) noted that higher educational institutions operate as complex organizations rooted in participatory democracy with highly professional and knowledgeable participants. This implies that management must seek to ensure effective involvement of staff and students in all aspects of school life. Similarly, Macek (2019) opine that, modern university managers are overseeing personnel who have skills they do not have. Therefore, they must turn to personnel for technical advice to make informed decisions. It therefore follows that, the achievement of the goals of any modern organization and universities in particular requires a collaborative, collective, or participatory approach.

Consequently, participatory management (PM) has been used interchangeably to mean shared governance, employee empowerment, employee involvement, participatory decision-making, dispersed leadership, open-book management, or industrial democracy. These coinages have evolved as a result of the long quest to enhance employee contribution to management decisions so as to achieve organizational objectives and productivity. Management in itself has been identified as a social activity involving working with and or through others in the organization to achieve organizational goals and objectives. This suggest the social and or participative nature of management. Therefore, to achieve the goals of university education, there is need for strategic, middle level and operational managers of universities to adopt a collaborative, collective, and integrative disposition towards planning, decision making and communication.

To participate means to work together. It involves the process whereby two or more persons or organizations work together to complete a task or achieve a goal. Participative management can also mean a purposeful relationship in which all parties strategically choose to cooperate in order to accomplish shared outcome. It is a shared governance approach which makes a balance between faculty and staff participation in planning and decision making. Kassa (2017) noted that a leader who uses collaborative management style rather than making all decisions, seeks to involve other people thus improving commitment and increasing collaboration which leads to better quality decisions and more successful organizations. participative management require both change in how management is conceptualized. Mangers in this context are expected to relate differently, absorb and integrate complexities in their institutions. This is essential because, the failure of a nation's higher education system can ruin the achievement of national development.

Consequently, the national policy on education FGN (2013) posits that a nation's national policy on education is government way of realizing that part of national goals which can be achieved using education as a tool. Therefore, education was further adopted as an instrument par excellence for achieving national development and by extension, the attainment of the goals and objectives of tertiary education will significantly contribute to the achievement of the overall goals of the nation. Therefore, tertiary institutions require effective management through intelligent planning, decision making and effective communication to achieve their goals and contribute meaningfully to overall national development. Planning can be seen as a process of carefully deciding in advance the best and possible ways of achieving set goals and objectives. Decision making on the other hand refers the intelligent rational process of choosing of the most optimum alternative for the attainment of the goals and objectives of an organization.

Gullick and Urwick (1973) outlined fundamental management practices to involve planning, organizing, staffing directing, coordinating, reporting and budgeting. Therefore, management is not a one-man affair. This is because all of its activities cannot be carried out in isolation of other members of the school; if the school must adequately achieve its goals. Regrettably, Kassa (2017) pointed out that a critical managerial challenge is the ability to mobilize others to want to get extraordinary things done in the organization. This involves the ability to 
collaborate or ensure adequate participation of critical stakeholders in the system through the development of a shared vision, mission and goals. This could be achieved through adopting a positive disposition towards involving relevant stakeholders in decision making, because when people plan or make decisions together, the social commitment to one another is greater and thus increases their commitment to the decision making, as well as several people deciding together make better decisions than one person alone.

Numerous studies on this subject point to the fact that employee involvement or participation in decision making does influence organizational commitment, job satisfaction and effectiveness (Osim et al., 2012; Mbon, 2017; Arop et al., 2019; Bassey et al., 2019; Madukwe et al., 2019). To some, it lowers absenteeism, enhance work attitudes, and higher individual work performance (Buch and Spangler, 1990) lower employee turnover and increase returns on equity, improve organizational learning culture. Adversely, it has also been shown that, when employees are not made to participate in decision making process, it leads to job dissatisfaction, lack of organizational commitment, low labour- management relations which reduce productivity.

Therefore, institutional managers are expected to adopt measures that ensure effective participation in the day to day administration of their institutions. Another method for enhancing participative management in universities is through the committee system or structure, university senate, faculty and departmental academic boards. Therefore, the increasing number of committees, and councils in universities in recent time is to avoid closed administrators' centered style of management and to move towards accommodating various opinions from school committees and encourage the participation of stakeholders. However, it is doubtful whether managers actually make use of resolutions, plans, and decisions reached in these committees and boards as guides for actions. Because, observation has shown that, the larger political scenario where small group of powerful individuals known as "cabal" in local parlance who undermine established institutions by high jacking decision making process is threatening the possibility of collective decision/planning in some Nigerian universities as it is gradually taking roots in the system.

However, Akuegwu (2016) posits that, it is the combination of organizational structure that shapes college and university administration. It is the organizational structure adopted by different organizations that creates a framework of order and command through which the activities of the organization can be planned, organized, directed and controlled. Therefore, the organizational structure adopted could influence stakeholders' participation/involvement in the planning and decision-making activities of an organization. Basically, they are three major organizational structural patterns operated in the university namely the line, line and staff and the committee. The line is occupied by those directly responsible for the achievement of the primary objectives of the institution, while the line and staff comprise of key actors on the line and subsidiary support staff who perform advisory roles in the organization and occupy the horizontal axis and provide support services to line staff.

In the line, and line and staff structure, an individual's rank, and position is key determinant of the level of participation in decision planning and decision-making process in the institution. On the other hand, the committee structures in tertiary institution is a major platform that ensures high level of participation of both academic and non-academic staff in the process of decision making in spite of level or rank. Akuegwu (2016) asserts that committees are meant for group involvement in institutional decision making and they facilitate task performance by enlisting the participation of staff in policy decisions. He further noted that committees constitute integral parts in the smooth operation of higher institutions worldwide. They are established at top management, faculty and departmental levels to cater for the administrative and academic needs and aspirations of the university, college, faculty, department or unit. 
For effective coordination, committees in colleges and universities are primarily divided into council, joint council/senate/academic board, faculty and Department. There is an inexhaustible catalogue of committees in universities, they include: council committee, senate/academic board, staff discipline committee, appointment and promotion committees, steering committee on endowed chairs and foundations, admission committee, research development committee, committee of deans among others. These committees afford for high participation of staff in the decision making and planning processes of the school. Therefore, the assertion that participatory approach to decision making and planning is a critical factor to employee commitment to the achievement of group goals is stating the obvious. Hence, the need to evaluate the nexus between collaborative management practices and institutional goal attainment in Nigerian universities.

\subsection{Statement of the Problem}

Nigerian universities have been berated overtime for many uncanny reasons by the press, parents, opinion leaders and the general public. Chief among the criticisms is the issue of the seemingly noticeable failure of universities to achieve its goals in terms of producing the right mix and quality of graduates needed to fast track national development. The seeming failure to achieve the objectives and goals of university education is assuming and alarming proportion thereby sparking loud public outcry that most Nigerian graduates are unemployable, and can neither read nor write effectively. This is worrisome given that poor quality of graduates is capable of crippling a nation's economic advancement. These issues have been attributed to general low funding of university education, inadequate school facilities, poor remuneration and general work conditions of staff among other things. Consequently, government has made commitment in the improvement of universities through TETFUND, shown willingness to embark on systemic revitalization, improved working conditions and salaries of university staff across board. Yet, many universities still fall below expectation in real sense.

This could be due to the missing link among various stakeholders in identifying the most critical factor (management approach) in the pursuit of organizational goals. Many university administrators adopt counterproductive management practices that do not involve members of the university community in decision making process and formulation of institutional plans. This they do in a pretext to avoid beauracratic bottlenecks, delay and unnecessary waste of time. Therefore, most plans and decision meet stern resistance from stakeholders due to dissatisfaction. This leads lack of commitment and poor performance thus dwindling the attainment of the goals of universities. This could be attributed to the failure of managers to adopt modern management practices that emphasize democratic principles of inclusion, collaboration, and collective participation. Therefore, the problem of the study is stated thus: how does participative management practices influence tertiary institution goal attainment.

\subsection{Research Questions}

1. What is the relationship between staff participation in decision making and institutional goals attainment?

2. What is the relationship between collaborative planning and institutional goals attainment?

\subsection{Hypotheses}

1. There is no significant relationship between staff participation in decision making and institutional goals attainment.

2. There is no significant relationship between collaborative planning and institutional goals attainment. 


\section{METHODS}

This study adopted the descriptive survey research design. The design was considered most appropriate for the study because variables of the study were ongoing activities in the school and the researcher only captured the picture of the phenomena as it existed at the time of investigation. The population of the study was 122 Deans of Faculties and Heads of Departments, comprising 15 Deans and 107 Heads of Departments. The census approach was adopted for the study because the population of the study is relatively small and manageable by the researcher. However, two hundred and thirty (230) randomly selected academic staff were respondents to the instrument.

The instrument used for data collection was a four-point Likert scale questionnaire titled: Participative Management Practices and Institutional Goal Attainment Questionnaire (PMPIGAQ). The instrument was designed by the researcher to collect data based on the variables of the study. The instrument was structured into two sections, section A was designed to elicit demographic information of respondents. Section B contained 18 items in a modified Likert scale of Strongly Agree (SA), Agree (A), disagree (D), and strongly disagree (SD).

The validity of the instrument was established by three experts in Higher Education Administration and Measurement and Evaluation. The Cronbach's reliability method was adopted for the reliability of the instrument. It yielded alpha ranging from $\alpha=.75-86$. Data were collected and analyzed through mean, Standard deviation, Pearson Product Moment Correlation Analysis.

\subsection{Presentation of Results \\ 2.1.1. Hypothesis One}

There is no significant relationship between staff participation in decision making and institutional goals attainment. Pearson product moment correlation was used to test this hypothesis at .05 level of significance. The results presented in Table 1 shows that $(\mathrm{r}=.78, \mathrm{p}<.05)$. Since $\mathrm{p}(.000)$ is less than $\mathrm{P}(.05)$, the null hypothesis was rejected. This implies that, there is a significant relationship between staff participation in decision making and institutional goal attainment.

Table-1. Pearson product moment correlation analysis of the relationship between participative decision making and institutional goals attainment. ( $\mathrm{N}=230)$.

\begin{tabular}{|c|c|c|c|c|c|}
\hline Variables & $\mathbf{X}$ & SD & df & R-Cal. & Sig. \\
\hline \multirow[t]{2}{*}{ Participation in decision making } & 14.04 & 3.10 & & & \\
\hline & & & 228 & $.78^{*}$ & .000 \\
\hline Institutional goals attainment & 13.35 & 3.14 & & & \\
\hline
\end{tabular}

\subsubsection{Hypothesis Tro}

There is no significant relationship between participative planning and institutional goals attainment. Pearson product moment correlation was used to test this hypothesis at .05 level of significance. The results presented in Table 2 bellow shows that $(\mathrm{r}=.48, \mathrm{p}<.05)$. Since $\mathrm{p}(.000)$ is less than $\mathrm{p}(.05)$, the null hypothesis was rejected. This implies that, there is a significant relationship between participative in planning and institutional goal attainment.

Table-2. Pearson product moment correlation analyses of the relationship between participative planning and institutional goals attainment. (N=230).

\begin{tabular}{|c|c|c|c|c|c|}
\hline Variables & $\mathbf{X}$ & SD & df & R-Cal. & Sig. \\
\hline Participation in planning & 15.53 & 3.00 & & & \\
\hline & & & 228 & $.48 *$ & .000 \\
\hline Institutional goals attainment & 13.35 & 3.14 & & & \\
\hline
\end{tabular}




\section{DISCUSSION OF FINDINGS}

The study revealed that participative planning and decision practices enhanced institutional goal attainment. The direction of the findings of the study could be because, planning itself is a conscious, proactive, purposeful activity involving determining in advance on the best possible means of achieving the goals of an institution. Planning by its very nature requires consensus building, collaboration and participation for effective achievement of the goals and objectives of any university.

Adequate participative planning practices which ensure the involvement of all staff in the university boost their morale, enhances transparency, ensures commitment, and motivation of staff to pursue and achieve the goals and objectives of the university.

This is because, a motivated team of committed employees is fundamental to the attainment of the goals of university education. The involvement of academic staff at departmental and faculty board as well as different committee levels at regular intervals for planning and the development of institutional programmes and activities gives a sense of recognition, importance and commitment among members of the university and motivate them to go extra mile in carrying out institutional plans and objectives.

The findings of the study are in tandem with the findings of Minor (2003) which revealed that over $67 \%$ of faculty believe there was a significant level of trust between faculty and management who effectively involved faculty in institutional decision making and planning and that this enhanced progress in the pursuit of institutional goals and objectives.

Minor further revealed that faculty participation in decision making at the departmental level, in standing faculty/administrative committees, and on ad hoc committees each have a significant and statistical impact on institutional effectiveness.

This is so because high level of faculty involvement ensures accountability and transparency in the management of institutions thereby building trust among faculty members and promote the achievement of institutional goals and objectives.

Similarly, Kater and Levin (2004) found key areas of faculty participation to include: grievance, curriculum, faculty evaluation process, sabbatical recommendations, retrenchment and the college calendar. On the other hand, McCormick and Meiners (1998) found that increased faculty participation in in institutional governance had a negative impact on the overall quality of an institution. This could be due to over engagement with administrative responsibility which reduce time for teaching and students' supervision.

However, the second findings of the study were that there is a significant relationship between participative planning and institutional goal attainment.

Managers of universities cannot achieve the objectives of the university education without adopting participative planning because, effective planning is not a one-man affair rather, it involves series of actions and activities that rely on both primary and secondary data from every unit, department and faculty in the university. Hence, systemwide planning whether at micro and macro (department and faculty board meetings, committee and senate) levels require bits of information from the least to the top organizational members.

Additionally, the specific chain of activities involved in planning and decision making such as system evaluation, collection of relevant data, development of objectives, selecting the optimum alternative, plan implementation and plan evaluation are inter-connected activities that require input from all stakeholders in the university in spite of their rank for the achievement of the goals and objectives of the university. 


\section{CONCLUSION}

Based on the strength of the findings of the study, it was concluded that participative management practices such as participative planning and decision making in school has statistically significant relationship with institutional goal attainment in university of Calabar. In other words, the effective involvement of faculty members in planning and institutional decision-making process enhance the goal attainment because, it facilitates transparency, feeling of self-worth thus promoting a sense of responsibility and commitment to the pursuit of institutional objectives and plans.

\section{RECOMMENDATIONS}

The following recommendations were made for the study

1. Managers of universities should promote participatory management practices to enhance high morale, commitment and enthusiasm among staff in the pursuit and attainment of institutional goals.

2. Managers of universities should avoid non-democratic management practices that could negate the achievement of the overall goals of their institutions.

\section{REFERENCES}

Akuegwu, B.A., 2016. Higher education administration: Organization and structure. In C. M. Uche; S. C. Anyamele; L. Nwikina \& J. N. D. Meeyinikkor (Eds). Administration and Organization of Higher Education: Theories, Tasks and Techniques.

Arop, F.O., V.J. Owan and E.C. Madukwe, 2019. Human resource management and teachers' job performance in secondary schools in Akamkpa Local Government Area of Cross River State. Nigeria. International Journal of Social Sciences and Management Research, 5(2): 27-34.

Bassey, B.A., V.J. Owan and E.A. Eze, 2019. Nexus between students', teachers' and school system effectiveness: Construction and factorial validity of a measuring instrument. British Journal of Education, 7(7): 62-75.

Buch, K. and R. Spangler, 1990. The effects of quality circles on performance and promotions. Human Relations, 43(6): 573582.Available at: https://doi.org/10.1177/001872679004300605.

Federal Government of Nigeria, 2013. National policy on education. Lagos: NERDC Press.

FGN, 2013. National policy on education. Lagos: NERDC Press.

Francis, D.I., 2015. Solving the problem of poor quality of university graduates in Nigeria- a holistic approach. British Journal of Education, 3(7): 52-70.

Gullick, L. and L. Urwick, 1973. POSDCORB. New York: Institute of Professional Administration.

Kassa, Y., 2017. Practices and challenges of participatory leadership in secondary schools of Nifas Silk Laftob Sub-City. Unpublished thesis submitted to school of Graduate Studies, Addis Ababa University.

Kater, S. and J.S. Levin, 2004. Shared governance in the community college. Community College Journal of Research and Practice, 29(1): 1-23.Available at: https://doi.org/10.1177/0091552117700490.

Koroma, J., 2018. Collaborative management practices. International Journal on Data Science and Technology, 4(3): 93-99.

Macek, J.F., 2019. Why collaborative management is successful.

Madukwe, E.C., V.J. Owan and B.I. Nwannunu, 2019. Administrative networking strategies and principals' supervisory effectiveness in secondary schools in Cross River State, Nigeria. British Journal of Education, 7(4): 39-48.

Mbon, U.F., 2017. Headteachers' managerial behaviour and teachers' task performance in public primary schools in CalabarSouth Local Government area, Cross River State, Nigeria. Global Journal of Educational Research, 16(2): 163169.Available at: https://doi.org/10.4314/gjedr.v16i2.11. 
McCormick, R.E. and R.E. Meiners, 1998. University governance: A property rights perspective. The Journal of Law and Economics, 31(2): 423-442.

Minor, J., 2003. Assessing the senate: Critical issues considered. American Behavioural Scientist, 46(7): 960-977.Available at: https://doi.org/10.1177/0002764202250122.

Ogunruku, A.O., 2010. Statutory bodies in universities: Roles, organizational structure and functions. Paper Delivered at a retreat for Members of Council of University of Agriculture, Abeokuta.

Osim, R.O., C.C. Uchendu and U. Mbon, 2012. Management's innovative behaviours and task performance among secondary school teachers in Cross River State, Nigeria. Journal of Emerging Trends in Educational Research and Policy Studies, $3(5): 661-664$.

Online Science Publishing is not responsible or answerable for any loss, damage or liability, etc. caused in relation to/arising out of the use of the content. Any queries should be directed to the corresponding author of the article. 